\title{
The Framing of Indigenous Canadian Families: A Historical Discourse Analysis
}

\author{
Amber Pfliger ${ }^{1}$
}

\begin{abstract}
To gain a comprehensive understanding of how Indigenous Canadian family life is framed in Canadian newspapers, 160 years of discourse was examined. To accomplish this analysis, newspaper articles were coded for themes relating to family and parenting, which was then compared to framing theory (Entman, 1993). This study concluded Indigenous families can be recognized through three distinct eras, each of which contributes to the development of discourse and the framing of Indigenous families. These findings are discussed concerning cultural framing and its effects on Indigenous populations.
\end{abstract}

\footnotetext{
${ }^{1}$ MacEwan University
} 


\section{Introduction}

During the totality of Canadian history, Indigenous people have been framed by news media in a multitude of ways. Arguably, these framed representations have shifted alongside changing cultures, laws, and political ideologies. According to Robert M. Entman (1993) news media acts as an active site of framing as it can determine addition of inaccurate information and the omission of relevant information (p. 54). Knowing this, it becomes clear as to how inaccurate framing can hold negative implications for the framed population. Moreover, these shifts have developed alongside dominant discourse, which has shaped how society consumes information. Because of this, many scholars have taken to the task of understanding the development of discourse through varying analyses, and the role they play within stereotyping, formulating prejudices, and facilitating overt forms of racism (Anderson \& Robertson, 2011., Longstaffe, 2017., Knopf, 2010., Strass \& Vogel, 2018., Hearne, 2017). Specifically, scholars have contextualized such discourse development through representations in media and have looked to understand the way discourse is utilized to represent Indigenous peoples (e.g., Clark, 2014., Hearne, 2017., Longstaffe, 2017., Lam, Cunsolo, Sawatzky et al., 2017). Henceforth, this paper intends to add to a growing body of research surrounding Indigenous media representation through a content and discourse analysis.

Consequently, this paper will investigate the framing of Indigenous family within Canadian newspaper articles from 1860-2019. In doing so, I hope to gain insight into the evolution of how Indigenous family representation changed alongside dominant Canadian discourse. The 160 years focused on within this research project will be divided into three proposed eras. Conceivably, the three eras emphasized will reflect shifts in the representation and discourse surrounding Indigenous Canadian families. The first date range of 1860-1930 can be characterized as the era of the Indian Act. Arguably, the Indian Act of 1876 can be considered the first significant shift in the perception of Indigenous families. That is, the passing of the Indian Act confirmed the notion that Indigenous populations were inferior to Europeans and that for them to assimilate into Canadian society, they would be to be regulated (Borrows, 2016, p.5). Ultimately, the Indian Act targeted the agency of Indigenous peoples as parents, spouses, and citizens. Going forward, we can then recognize the period of 1930-1980 as the era of Residential schooling. Throughout this time frame, Indigenous children were the targeted member of the family. Specifically, Indigenous children were violently removed from their families, regardless of parental protest, and forced to attend state-sanctioned boarding schools. As a result, this era of Indigenous history is considered to be one of the most significant intrusions of Indigenous family life (Anderson, Miller and Newman, 2018, p. 317., Ing, 2006). Lastly, 1980-2019 can be recognized as the era of Truth and Reconciliation. Arguably, this era acknowledges Canada's colonial legacy and emphasizes the importance of Indigenous healing (Anderson, Miller \& Newman, 2018, pp. 316-317). Notably, this era also highlights government calls to action and growth. Therefore, these proposed eras will be used to contextualize the research findings and situate the newspaper articles within distinct historical periods. 


\section{Who are Indigenous Families?}

For this research, the term "Indigenous" will be used to encompass an extensive regional and cultural variation in heritage. Traditionally within Canada, the term has been used to describe those of First Nations, Metis, and Inuit descent (Todd, Thornton, and Collins., 2001, p. 10). Due to the nature of this research, few data sources explicitly stated specific Indigenous nations, making it difficult to determine which Indigenous nation was being referred to. Currently, Canada recognizes over seventy different Indigenous nations. Therefore, the term Indigenous is not used to homogenize, but rather aid in the development of both content and discourse analysis.

\section{Methods}

To gain a comprehensive understanding of the framing of Indigenous families in Canada, I utilized ProQuest Historical Newspapers: Globe and $\mathrm{Mail}^{2}$ to secure newspaper articles. This database was chosen as it projected Canadian based content and allowed the user to select both the date range and type of article to be displayed. With ProQuest Historical Newspapers, I was able to search for newspaper articles by using search phrases such as "Indigenous" and "family." Due to the limited amount of newspapers featuring "family," the search phrases had to be expanded to include "parenting" and "children." Fortunately, this rendered more results. Due to the historical nature of this research project, relevant racialized terms such as "Indian" and "native" were used in conjunction with "family," "parenting," and "children." From here, the ProQuest Historical Newspaper database responded with a wide-ranging list of newspaper articles. Using these results, I then narrowed the search to include articles from each selected date range (e.g., 1860-1930). After the results rendered, I then used purposive sampling based on the following criteria: the newspaper article featured at least two of the search phrase words, and it was sorted as a frontpage article. By utilizing these criteria, I was able to omit articles that were irrelevant to the initial research question. ${ }^{3}$

The above methods allowed for the selection of nineteen newspaper articles ${ }^{4}$, each of which represented itself in one of three proposed eras of Indigenous Canadian history. As mentioned, these periods range from 1860-1930, 1930-1980, and 1980-2019. By utilizing online newspaper articles, I was able to use readily available information required to perform a content analysis. The content analysis consisted of a coding scheme in which aspects that were related to Indigenous family (such as parenting or childcare) was emphasized. That is, I focused my attention on how newspapers discussed and framed Indigenous family life concerning familial functions. Furthermore, the coding scheme also recognized the author, the tone of the article, and the indented

\footnotetext{
${ }^{2}$ ProQuest Historical Newspapers: Globe and Mail database was accessed through the MacEwan Library system.

${ }^{3}$ After the initial coding phase, McLaren, C. (1980), “4-H Club Won't Visit Six Nations Reserve” was omitted in addition to a duplicate article.

${ }^{4}$ See Appendix for full list of newspaper articles referenced in this study.
} 
audience. In doing so, I believe I was able to build a comprehensive understanding of how newspaper articles acted as an active site of framing during each of these proposed periods.

\section{0-1930: The Era of Colonization and the "Indian Act"}

The first proposed era is characterized by both colonization and the Indian Act of 1876 . Arguably, this era can be considered the beginning of a significant shift in the perception of Indigenous Canadian families. That is the passing of the Indian Act altered how Indigenous peoples would be viewed in relation to European settlers. Unfortunately, this included a Eurocentric view of Indigenous culture, most noticeably when involving parenting, child-rearing, and marriage. Moreover, the passing of the Indian Act confirmed preconceived European notions that Indigenous peoples were 'inferior' to Europeans and that for Indigenous peoples to assimilate into 'proper' Canadian society, they would need to be regulated (Borrows, 2016, p. 5). As a result, the Indian Act of 1876 removed agency from Indigenous peoples and prompted a long history of viewing Indigenous families in a paternalistic nature (Anderson, Miller and Newman, 2018, p. 311).

While analyzing the first group of newspaper articles, important themes quickly emerged. Firstly, within the newspaper articles, there were few direct references to Indigenous family units. That is when the family was discussed, it was often in relation to familial parts such as children, fathers, and mothers. Arguably, this can be considered a result of family boundary ambiguity (Boss, 1977, pp. 144-145). As mentioned by Tam, Findlay and Kohen (2017), family ambiguity can be theorized as indistinct familial organizations that are the result of a range of non-traditional family types, which can lead to misunderstood conceptualizations of Indigenous family (p. 426). As such, journalists of this period acted as outsiders looking in, often using a Eurocentric lens while discussing family and parenting. For example, in the newspaper article "Preventable Child Mortality" (1862), the concept of child mortality is questioned through the first-hand account of a non-Indigenous Mr. Catlin, an ethnographical researcher. Specifically, within the article, it is noted that Mr. Catlin prompted an inquiry into the parenting practices of Indigenous women of the 'tribe,' as he was unconvinced their low infant mortality rate could be attributed to accidents or 'laws of nature.' As well, within the newspaper article, there is no direct reference to Indigenous groups as families, but rather the notion that all Indigenous peoples live together within villages.

A secondary theme that emerged concerning Indigenous families was that of marriage. Interestingly, two of the articles from this era focused on what was considered 'legitimate' marriage and whether Indigenous ceremonies could be included as such. For instance, in the newspaper article titled "The Validity of Indian Marriages" (1869), the writer expresses concern surrounding a widow who is looking to absorb her late husbands' estate. Because the wife was of Indigenous descent, she and her late husband partook in an Indigenous ceremony, which was ultimately viewed to be illegitimate in contrast to European marriages. Surprisingly, the woman's case was brought forth to a judge, who ruled in favour of the widow and called for the case to be appealed in England. As mentioned, marriage was also emphasized in a second article. In "The Marriage Customs" (1894), the writer references the absence of paternal decent patterns after marriage and the absence of written laws regarding intermarriage. Explicitly, the writer expresses confusion regarding the perceived strength of these unwritten laws, which suggests that Indigenous kinship systems are not recognized (nor understood) by European counterparts. 
As the era of colonization and the Indian Act moved forward, it became apparent within the remaining articles that in cases where Indigenous family life was mentioned, it was concerning parenting style. Arguably, when discussing the representation of Indigenous families, we must look at it holistically. This includes looking at notions of parenting, which can be viewed as a task that is generally taken on by parent(s) within the family. Typically, inadequate representations of Indigenous parenting manifests itself through the over-representation of incarcerated parents and those who currently have their children in care (Hardy, 2018; Byle 2019, Barker et al, 2019). Additionally, it was noted that within the reviewed newspaper articles that when parenting was mentioned, it was often weighted on mothers and framed within a negative light. These negative interpretations often included Indigenous mothers as callous, uninvolved, and distinctly different than their European counterparts. For instance, in the newspaper article "Given to Indians" (1903), the writer refers to a woman who has had a non-Indigenous child placed in her care. Rather than recognizing this action as selfless, the writer persists "...complaints had been made of the miserable creature who was acting as its guardian. She has been drinking heavily and was giving the child scant nourishment, and altogether improper care." Here, we can see the framing of Indigenous parenting through the role of mothering as in poor quality, even when raising nonIndigenous children. That is, the writer neglects the reality of Indigenous parenting and the minimal availability of resources that Indigenous parents can access. Thus, providing a singlesided frame of Indigenous parents.

In rare cases where dual Indigenous parenting was mentioned, it was viewed as 'less than.' For instance, in the newspaper article "Eaten by Wolves" (1905), the writer suggests that the fate of an Indigenous family's children was not decided by chance, but rather bad parenting practices. In this case, the writer explains that "two young Indian children, who were deserted and unprotected, were eaten alive [by wolves]," and "[the father] had deserted his adopted children in the bush some time during last September." Although it is arguable that a lack of supervision, hence parenting could have played a role in this outcome, this article ignores the ease in which young children can find themselves in troubling situations. Moreover, the article neglects to provide any first-hand accounts from the parents in question, thus supporting a framed understanding of Indigenous parenting. Furthermore, within the newspaper article, the writer mentions that neighbouring Indigenous communities headed a search and rescue effort to find the missing children, but their efforts were insufficient. Interestingly, this article includes a written diary entry by a Police Force Sargent yet does not include any police involvement or deployment of services in search efforts. Thus, even when Indigenous parenting is recognized as insufficient or in poor quality, the lack of involvement from larger acting forces (such as the police) suggests that it remains an individualistic problem of a 'people.'

\section{0-1990: The Era of Residential Schooling \& Assimilation}

The second era proposed is that of the Residential schooling period in Canada. Residential schools can be recognized as one of Canada's greatest sources of disgrace as it sought the forceful removal of children from their family environments for European assimilation. Practices of assimilation included 'civilizing' Indigenous children to European standards and ultimately acted 
as a step in doing away with the "Indian Problem" (Rheault, 2011, p. 3). As mentioned by Anderson, Miller, and Newman (2018), the initial premise of Indigenous educational institutions was supported by both the government, church, and Indigenous parents (pp. 311-312). However, as broken Treaty promises mounted, Indigenous parents became untrusting of the motives surrounding formal Indigenous education, but due to the passing of the Indian Act they were unable to resist (pp. 312-313). Arguably, the cornerstone of Indigenous family life suffered greatly during this era, as Indigenous parents were "strongly encouraged...to send their children to residential schools" and "had to sign over custody of their children to the school superintendent or principal, by law" (Rheault, 2011, p. 2).

While investigating representation during this era, a continuing theme emerged. That is the framing of Indigenous parents as 'less than' continued forward as dominant discourse. Specifically, this theme is recognized in three of the articles studied from this era. In two of the three articles, the writers refer to Indigenous parents as absent, in poor financial standing, uneducated, and in one article - cannibalistic. Although the reference to Indigenous people as cannibals was only mentioned once, it was nonetheless surprising. This reference was found in the newspaper article "Two Children Eaten: Woman Recalls Indian Cannibalism of 84 Years Ago" (1935). Within the article, the writer focuses on a retelling of a woman's recollection of a harsh winter of 1851, where during a fur trade run, she encounters an Indigenous family and takes notice of their shrinking family size. Ultimately, the woman concludes that the unforgiving Canadian winter prompted the Indigenous parents to eat their youngest children, thus reducing their family size. Although the date referenced is around 1851, the publication date of the newspaper article is 1935, which falls within the proposed era. Interestingly, the writer includes in the article that as a child, the woman was told "tales of Indians eating their children" but fails to provide an alternative explanation for such a conclusion. Arguably, this suggests that the writer was not in disagreement with this story and failed to see the harm in publishing such an outrageous event without any defense of the Indigenous parents mentioned. Thus, adding to dominant discourse surrounding Indigenous parenting and child-rearing.

As mentioned above, Indigenous parenting is framed as absent and unequipped to properly rear children. Because of this, the Indigenous family is represented as un-intact and broken. For instance, in the newspaper article titled "It's the Indian Children Who Suffer in Armstrong" (1968), Rudy Platiel (the case reporter) investigates the conditions that Indigenous children will be facing on their Reservation during Christmas. Interestingly, Platiel includes anecdotes within the article that encompasses Indigenous parents as deserting their children for drinking, not providing adequate housing, and overall being unable to provide a "proper" Christmas. For instance, Platiel notes "...in other cabins, Indian children spent Christmas Eve alone - left by parents who have gone off to celebrate," and "Father Bazinet said that often welfare money is spent on liquor and beer while the children have only a bag of potato chips for supper." Here, Platiel compares poor parenting to not providing a subjectively adequate Christmas to their children. Arguably, this supports a Eurocentric view and an assimilationist value that would have been encouraged at this time. As well, it does not recognize the cultural differences that exist between Indigenous and European traditions, such as Christmas being a Christian holiday. Furthermore, the forceful removal of children during the Residential school era propelled a disproportionate number of Indigenous parents into interaction with the child welfare system (Byle, 2019, p. 22). Because of 
this, Indigenous parents may not have the skills or resources needed to foster healthy relationships with their children. Therefore, this article disregards the social and systemic barriers Indigenous families were facing such as poor Reserve conditions and the lack of financial resources. Ultimately, blaming parenting practice on individualized notions of ability.

Interestingly, it is within the era of Residential schooling and assimilation that the discourse surrounding Indigenous family begins to shift. Specifically, within this era, Indigenous parents are recorded in newspapers defending the rights and needs of their children. For instance, two of the articles analyzed in this era featured Indigenous parents vocalizing concerns over children being removed from their homes and the poor conditions of Residential education facilities. Again, we see this in the article "It's the Indian Children who Suffer in Armstrong" (1968) by Rudy Platiel. Here, Platiel notes that "treaty Indian parents sent a letter to the federal government... asking for their children to attend school in Armstrong rather than be sent to boarding school." Parents acting in their children's defense are also recognized in the newspaper article "Indian Children Deserve Better Treatment" (1971), where Indigenous parents are represented as active participants in their children's education, health, and happiness. Here, we receive an account of Indigenous parents removing their children from school in protest of poor Reserve conditions and inadequate educational facilities. When looking at all the newspaper articles analyzed for this study, the above article is the first that brings awareness to poor reserve conditions. As mentioned by Lam, Cunsolo, \& Swatzky et al. (2017), the representation of Indigenous needs regarding infrastructure and drinking water often receives limited coverage, even into the present day (p. 14). Thus, it is surprising that this newspaper article was published, especially as a front-page article. Furthermore, in "Indian Children Deserve Better Treatment" (1971), the writer chronicles the parent's movement reaching Ottawa, and the forcefulness of Indigenous parents in an attempt to be heard. Although the writer does frame Indigenous parents as active, the writer includes a quote that encompasses the difficulty Indigenous parents face when attempting to create large-scale change for their children "...When the Indians killed the white man, well, it's a massacre, but the other way around, it's a victory. The Indian's a savage, not hero, he's no person in a book. He's nothing!" Arguably, this quote reduces the imperative needs of Indigenous families as trivial, promoting them being viewed as nothing more than "Indian."

Furthermore, during this era, non-dominant discourse begins to proliferate in defense of Indigenous family. For instance, in "It's the Indian Children Who Suffer in Armstrong" (1968) Platiel provides the commentary of both Hector King, the Metis president of the Armstrong Indian Association, and Edward Johnson, the school board chairman. Within the article, Mr. King is quoted as conceptualizing Indigenous parents drinking habits as a result of "[being] separated from their children" and Mr. Johnson is quoted saying "you can't really blame the parents because they didn't have any home life, so they don't know how to make one." Moreover, the remaining articles analyzed within this era express recognition of the distinct social problems that Indigenous people face, suggesting a lack of resources has led them to their circumstances. For instance, in the newspaper article "Indian Children as Smart as Whites, Pathologist Tells Association" (1970), written by Jo Carson, psychologist Dr. G.A. Milton confirms that indeed, differences recognized in intelligence can be contributed to ethnocentrism and when measured must be viewed through a relativistic lens. Moreover, within the article, Dr. G.A. Milton also criticizes the federal government for the implementation of the Residential school system as he recognizes the lasting developmental and social effects it had on children. This change in discourse is also reflected in 
the remaining newspaper articles titled "Welfare Expert Says Staff Lack Keeps Indian Families Split Up" (1970) and "9 Babies per Indian, MPs Told" (1969). In each of these articles, the writers recognize the current deficits in child and family welfare as a result of government legislation. Thus, each article emphasizes Indigenous families being held in relation to government policy and bringing forth the notion of government accountability and calls to action.

\section{0-2019: The Era of Truth and Reconciliation}

Although the last Residential school in Canada closed its doors in 1996, the effects of its atrocities remain. Arguably, the 1990s encompassed challenging discussions with survivors and the recognition of a failed genocide (Anderson, Miller \& Newman, 2018, pp. 316-317). Most importantly, this era included the creation of the Truth and Reconciliation Commission in 2008, which provided a platform for Indigenous healing and growth (Woolford, 2009, p. 55). However, when analyzing newspaper articles from this era, it becomes apparent that Indigenous peoples were not being represented as survivors but instead framed as victims. Initially, victim framing can be recognized in the newspaper article titled "Indians' Stark Reality: A Life of Poverty and Family Breakdown" (1980). In this article, Robert Sheppard debriefs on the federal government's newly released report on the economic and social well-being of "Canadian Indians" and concludes that Indigenous families are the victims of government policy and malpractice. However, Sheppard also notes that although current Indigenous affairs are subpar, they are better than that of the prior Indigenous generation. Thus, even when the Indigenous family is represented as victims, there is still an essence of disregard for the true intergenerational effects of colonized Indigenous history.

Nonetheless, during this era, newspapers did shed light on the countless violations of the Residential school system and argued for the decolonization of child welfare. According to Byle (2019), the decolonization of child welfare includes providing appropriate staff to help with intergenerational healing, changing policy to support Indigenous families, and increased family reunification (pp. 24-26). The promise of change is reflected in the newspaper articles featured within this era. For example, the article "Hundreds of Cree and Ojibwa Children Violated" (1996) discusses the fallout of St. Anne's Residential school. Here, Peter Moon provides survivor accounts on the abuses suffered and attempts to represent Indigenous children as victims of circumstance. That is, Moon provides context into why Indigenous parents were likely to allow for the removal of their children as he writes, "if parents objected... they were told by missionaries that their family and welfare cheques would not be cashed and that local stores, most of which were run at the time by the Hudson's Bay Co., would not grant them credit." Although arguably, this passage provides context, it negates the many other reasons why Indigenous parents would be unable to refuse their children's enrolment in the Residential school system, such as coercion, violence, and police involvement. Interestingly, out of all the articles used in this analysis, Peter Moon's title was the only to include the specific Bands of Indigenous children harmed. Arguably, the use of specific Band names in the title suggests the de-homogenization of Indigenous peoples and the recognition of individual differences.

The remaining newspaper articles written within this era continue to reflect the changing discourse surrounding Indigenous family life. Noticeably, this manifests itself as calls towards 
government apology and action. As mentioned, this change is arguably an outcome associated with the Truth and Reconciliation Commission. Consequently, the newspapers of this era begin to frame Indigenous families in relation to the Truth and Reconciliation movement. For instance, in the article "Indigenous Partners, Not Prisoners" (2013) by Stephen Huddart, the writer expresses the evolution of Indigenous families from broken homes to successful futures, boasting the many benefits of alternative Indigenous community programming and the importance of the Truth and Reconciliation Commission. This theme is echoed in "Manitoba Moves to Overhaul Troubled Child-Welfare Services," where Kathryn Blaze Carlson discusses the Manitoba government's shift towards preventative family services. Arguably, the high-profile deaths of children in care, such as Tina Fontaine and Phoenix Sinclair, prompted highly requested calls for family reunification and a change in children's care resources. The government call to action was also mentioned in the article "Ottawa Looks to Rectify Sixties Scoop" by Kathryn Blaze Baum where she discusses Ottawa's plan to handle the repercussions of the "mass adoption of Indigenous children into nonIndigenous families". Again, this article represents Indigenous families in relation to policy and government change as the writer notes, "Children were not only separated from their parents and siblings, but they were stripped of their culture, and in some cases, subjected to physical and sexual abuse. Several lawsuits have been launched...including Manitoba, which last year became the first province to apologize for the sixties scoop." Thus, demonstrating that even during the contemporary era, Indigenous family is being represented in relation to government action and policy.

\section{Discussion}

Through content analysis, this paper has established the changing discourse surrounding Indigenous families. However, it has yet to discuss what this means regarding media representations and their effect on Indigenous populations. Although each proposed era offered distinct representations, they shared commonalities. Firstly, throughout all the articles analyzed, there is a staggeringly low rate of direct reporting on Indigenous families. Arguably, this lack of reporting can be recognized through family ambiguity as early accounts of reporting on Indigenous family may have been skewed as the writers of the time could not consider anything outside of the nuclear family as "real" familial bonds (Tam, Findlay, and Kohen, 2017). Thus, it would have been trying for European journalists to report on Indigenous families as they may not have recognized Indigenous people as having families. Arguably, this is congruent with Entman's (1993) notion of "selection and salience" in which framing agents (such as newspaper writers) will add or remove aspects of their writing to aid in "promote[ing] a particular problem" (p. 52). For example, within the articles selected, few referred to alternative kinship systems. Because of this, the writers then represent the Indigenous family as non-existent or fractured. Henceforth, the removal of Indigenous family representation can alter the way society views Indigenous familial problems. Thus, aiding in the claim that Indigenous parents do not need family support services and the cultural alignment of policies. 
Secondly, many of the newspaper articles included in this study were written by, presumably, white men. Because of this, these writers would likely be adding to the dominant discourse. Unfortunately, even with social progress, this dominant discourse has yet to shift. As mentioned by Anderson and Robertson (2011), the representation of Indigenous people in newspaper media has not changed since the era of colonialization, and colonial discourse continues to be used when representing Indigenous peoples (p. 267). For instance, the first two eras researched focused quite heavily on the individual choices made within families, such as poor parenting and alcohol consumption. Additionally, this coincides with Entman's (1993) framing in that this media representation "defines a problem" (p. 52). Here, the 'problem' can be viewed as the individual actions of Indigenous people (such as drinking) that leads to their social disparities. Furthermore, Entman (1993) suggests that framing agents "make moral judgements" and "suggest remedies" such as those found in the newspapers studied. Typically, this manifested itself through the era of Residential schooling with the promotion of white saviourism and increased welfare intervention.

Lastly, many of the newspaper articles featured negative story building. That is, few of the articles encompassed Indigenous families being viewed in a positive light. Debatably, this can be considered a direct result of using front-page news articles and the destructive nature of media. Specifically, news media tends to overrepresent negative stories as they tend to sell the most papers or harvest the most engagement. Moreover, due to the dynamic nature of reporting, we can recognize newspapers as that of the communicator. According to Entman (1993), the communicator harbours the ability to make such frames through "deciding what to say" (p. 5253). Unfortunately, this causes a disproportionate representation of Indigenous families as 'less than', inadequate parents, and victims. As a result, it becomes easy to see how discourse can be utilized by the media to orchestrate a range of stereotypes, prejudices, and inaccurate information.

\section{Limitations}

Although this study renders noteworthy results, limitations were present. Primarily, using newspaper articles from 1860 posed reliability concerns. That is, due to the nature of these articles, it was difficult to utilize appropriate era terminology and comprehend the writer and intended audience. Unfortunately, this acted as a harsh reminder of the treatment of Indigenous peoples throughout Canadian history. As well, due to the age of the earliest articles, errors such as difficulty to read, and author clarity emerged. Additionally, only 20 newspaper samples were used to analyze nearly 160 years of discourse. By including more samples in this analysis, it would have aided in a more developed understanding of the discourse surrounding Indigenous family and perhaps provided even higher yield in themes. Unfortunately, due to time constraints, this was not possible. Furthermore, the articles chosen for this study were designated 'front page' articles. That is, this research study potentially ignored articles that could have provided evidence of alternative discourse. Lastly, due to the nature of this study, the term "Indigenous" unintentionally homogenized First Nations, Metis, and Inuit peoples of Canada. Because of this, I implore future researchers to investigate the discourse and framing surrounding specific Indigenous groups and compare their findings. 


\section{Conclusion}

Subsequently, this study demonstrated the historical implications that aid in the creation of discourse. Specifically, it reviewed how news media has been used to distribute themes that adhere to the stereotypes and prejudices of Indigenous families. By utilizing news media such as newspapers, it establishes that up to the present day, the representation of Indigenous families remains as broken, less than, and vulnerable. Moreover, it is worth noting that these representations continue into many other forms of media, all of which continue to perpetuate the Indigenous people of Canada in a negative light. Thus, as consumers of media, we must remain critical when assessing the representation of racialized groups within newspaper articles. That is, we must question whether the writers are relaying facts, or perpetuating stereotypes and prejudices. Unfortunately, due to the volatile nature of news media, we must always remain vigilant when assessing the narrative and the side of the discourse being displayed. Going forward, I implore future researchers to continue this line of research to better understand the impact of framing within the dominant discourse on Indigenous peoples of Canada. 


\section{References}

Anderson, A., Miller, D.K., Newman, D. (2018). Canada's residential schools and the right to family integrity. Dalhousie Law Journal, 41(2), 301-338.

Anderson, M. C., \& Robertson, C. (2011). Seeing red: a history of Natives in Canadian newspapers. University of Manitoba Press. Retrieved from https://library.macewan.ca/full-record/cat00565a/7391996

Barker, B., Sedgemore, K., Tourangeau, M., Lagimodiere, L., Milloy, J., Dong, H., ... DeBeck, K. (2019). Intergenerational trauma: The relationship between residential schools and the child welfare system among young people who use drugs in Vancouver, Canada. Journal of Adolescent Health, 65(2), 248-254. https://doi.org/10.1016/j.jadohealth.2019.01.022

Borrows, J. (2016). Unextinguished: Rights and the Indian act. University of New Brunswick Law Journal, 67, 3-35. Retrieved from https://library.macewan.ca/fullrecord/a9h/117026434

Boss, P. (1977). A clarification of the concept of psychological father presence in families experiencing ambiguity of boundary. Journal of Marriage and Family, 39(1), 141. https://doi.org/10.2307/351070

Byle, A. P. (2019). Decolonizing child welfare. Herizons, 33(1), 22. Retrieved from https://library.macewan.ca/full-record/p3h/136453564

Clark, B. (2014). Framing Canada's aboriginal peoples: A comparative analysis of Indigenous and mainstream television news. Canadian Journal of Native Studies, 34(2), 41-64. Retrieved from https://library.macewan.ca/full-record/31h/108357883

Rheault, D. (2011). Solving the "Indian problem" assimilation laws, practices \& Indian residential schools. Retrieved from https://www.omfrc.org/wpcontent/uploads/2016/06/specialedition8.pdf

Entman, R. M. (1993). Framing: Towards clarification of a fractured paradigm. Journal of Communication, 43 (4), 51-58. https://doi.org/10.1111/j.1460- 2466.1993.tb01304.x

Hardy, Jessica. Parental incarceration's effect on family: Effects on mothers, fathers, marriage, children and socioeconomic status. Canadian Journal of Family and Youth (online). https://journals.library.ualberta.ca/cjfy/index.php/cjfy/issue/view/1940

Hearne, J. (2017). "I am not a fairy tale": Indigenous storytelling on Canadian television. Marvels \& Tales: Journal of Fairy-Tale Studies, 31(1), 126-146. Retrieved from https://library.macewan.ca/full-record/edspmu/edspmu.S1536180217100074

Ing, R. (2006). Canada's Indian residential schools and their impacts on mothering. In Lavell, J. C., \& Lavell-Harvard, D. M ( $1^{\text {st }}$ ed.) Until our hearts are on the ground: aboriginal mothering, oppression, resistance and rebirth. Toronto, Ont. Demeter Press.

Lam, S., Cunsolo, A., Sawatzky, A., Ford, J., and Harper, S.L. (2017). How does the media portray drinking water security in Indigenous communities in Canada? An analysis of Canadian newspaper coverage from 2000-2015. BMC Public Health, (1), 1. https://doi.org/10.1186/s12889-017-4164-4

Longstaffe, M. (2017). Indigenous women as newspaper representations: Violence and action in 1960s Vancouver. Canadian Historical Review, 98(2), 230-260. https://doi.org/10.3138/chr.3215 
Tam, B. Y., Findlay, L. C., \& Kohen, D. E. (2017). Indigenous families: who do you call family? Journal of Family Studies, 23(3), 243-259. https://doi.org/10.1080/13229400.2015.1093536

Todd, Roy; Thornton, Martin; Collins, D. N. (2001). Aboriginal people and other Canadians: shaping new relationships. University of Ottawa Press.

Woolford, Andrew. (2009). The Politics of Restorative Justice: A Critical Introduction. Black Point, NS: Fernwood Publishing. 


\section{Appendix}

Preventable Infant Mortality. (1862). Retrieved from https://search-proquestcom.ezproxy.macewan.ca/docview/1516398842?accountid=12212

The Poor Indian: An Ill-fated Family (1863). Retrieved from https://search-proquestcom.ezproxy.macewan.ca/docview/1516512946? accountid=12212

The Validity of Indian Marriages. (1869). Retrieved from https://search-proquestcom.ezproxy.macewan.ca/docview/1519004083?accountid=12212

The Marriage Customs. (1894). Retrieved from https://search-proquestcom.ezproxy.macewan.ca/docview/1649265636?accountid=12212

Given to Indians. (1903). Retrieved from https://search-proquestcom.ezproxy.macewan.ca/docview/1353929336?accountid=12212

Eaten by Wolves. (1905). Retrieved from https://search-proquestcom.ezproxy.macewan.ca/docview/1354954534?accountid=12212

Two Children Eaten. (1935). Retrieved from https://search-proquestcom.ezproxy.macewan.ca/docview/1350755404?accountid=12212

Justice for All. (1957). Retrieved from https://search-proquestcom.ezproxy.macewan.ca/docview/1288623335?accountid=12212

Platiel, R. It's the Children who Suffer in Armstrong. (1968). Retrieved from https://searchproquest-com.ezproxy.macewan.ca/docview/1242409860?accountid=12212

9 Babies per Indian, MPs Told. (1969). Retrieved from https://search-proquestcom.ezproxy.macewan.ca/docview/1242180982?accountid=12212

Welfare Expert Says Staff Lack Keeps Indian Families Split Up. (1970). Retrieved from https://search-proquestcom.ezproxy.macewan.ca/docview/1242193305?accountid=12212

Carson, J. Indian Children as Smart as Whites, Pathologist Tells Association. (1970). Retrieved from https://search-proquestcom.ezproxy.macewan.ca/docview/1242126805?accountid=12212

Indian Children Deserve Better Treatment. (1971). Retrieved from the Gateway, October 29, 1971, Page 4, Item Ar00400

Sheppard, R. (1980). Indians' Stark Reality: A Life of Poverty and Family Breakdown. Retrieved from https://search.proquest.com/hnpglobeandmail/docview/1124986939/BB5591C830B441B $\mathrm{CPQ} / 3$ ? accountid $=12212$

McLaren, C. (1980). 4-H Club Won't Visit Six Nations Reserve. Retrieved from https://search.proquest.com/hnpglobeandmail/docview/1124985503/FA16EE26E5524D0 9PQ/11?accountid $=12212$

Moon, P. (1996). Hundreds of Cree and Ojibwa Children Violated. Retrieved from https://search.proquest.com/hnpglobeandmail/docview/1137160769/310626D2EADF44C $\underline{0 P Q / 8 ? \text { accountid }=12212}$

Montour, E., Huddart, S. (2013). Indigenous Partners, Not Prisoners. Retrieved from https://search.proquest.com/hnpglobeandmail/docview/2273302583/BB5591C830B441B $\underline{\mathrm{CPQ} / 2 ? \text { accountid }=12212}$ 
Blaze-Carlson, K. (2015). Manitoba Moves to Overhaul Troubled Child-Welfare Services. Retrieved from https://search-proquestcom.ezproxy.macewan.ca/hnpglobeandmail/docview/1811444639/C608A25AE0204EEF $\mathrm{PQ} / 13$ ? accountid=12212

Blaze-Baum, K. (2016). Ottawa looks to rectify Sixties Scoop. Retrieved from https://searchproquestcom.ezproxy.macewan.ca/hnpglobeandmail/docview/2273302583/C608A25AE0204EEF $\underline{\mathrm{PQ} / 14 \text { ? accountid }=12212}$ 